\title{
Clinical Study of Decompressive Craniectomy in Children
}

\author{
Burcu GOKER ${ }^{1}$, D. Gucluhan GUCLU², llyas DOLAS ${ }^{3}$, Utku OZGEN³ ${ }^{3}$ M. Emre ALTUNRENDE ${ }^{4}$, A. Tolgay AKINCl ${ }^{5}$, \\ Fahir SENCAN ${ }^{6}$, Aydin AYDOSELI ${ }^{3}$, Halil CAN ${ }^{7}$, Altay SENCER ${ }^{3}$ \\ ${ }^{1}$ Istinye University School of Medicine, Liv Hospital-Ulus, Department of Neurosurgery, Istanbul, Turkey \\ 2University of Health Sciences, Bakırkoy Sadi Konuk Research and Training Hospital, Department of Neurosurgery, Istanbul, Turkey \\ ${ }^{3}$ Istanbul University, Istanbul School of Medicine, Department of Neurosurgery, Istanbul, Turkey \\ ${ }^{4}$ University of Health Sciences, Gaziosmanpasa Taksim Research and Training Hospital, Department of Neurosurgery, Istanbul, Turkey \\ ${ }^{5}$ Trakya University School of Medicine, Department of Neurosurgery, Edirne, Turkey \\ ${ }^{6}$ Istinye University School of Medicine, Liv Hospital-Bahcesehir, Department of Neurosurgery, Istanbul, Turkey \\ ${ }^{7}$ Biruni University School of Medicine and Medicine Hospital, Departments of Neurosurgery, Istanbul Turkey
}

Corresponding author: Burcu GOKER burcugoker79@yahoo.com

\section{ABSTRACT}

AIM: To evaluate the clinical characteristics of children who recently underwent decompressive craniectomy (DC) due to elevated intracranial pressure (ICP) correlated to head trauma or other causes, such as ischemic insult.

MATERIAL and METHODS: Twelve patients aged $\leq 17$ years who underwent DC due to elevated ICP between 2013 and 2018 were included in the study. The clinical status of the participants, radiological characteristics, type and timing of surgery, and outcomes were recorded.

RESULTS: Three female and nine male patients with a mean age of 10 years were included. The initial average Glasgow Coma Scale score was 6 (3-12). All patients presented with signs of diffuse cerebral edema and subdural hematoma of various sizes along with other intracranial pathologies. Only one patient required bilateral frontal craniectomy. In the postoperative period, three patients died, and three had severe disability.

CONCLUSION: With the increasing use and success of DC in adults, this procedure can also be effective in children. Considering brain differences in children, large and well-structured clinical trials must be conducted to prevent complications and to identify the best technique, timing, and benefits of DC for children.

KEYWORDS: Decompressive craniectomy, Pediatric, Traumatic brain injury, Intracranial pressure, Glasgow coma scale

ABBREVIATIONS: Decompressive craniectomy (DC), Traumatic brain injury (TBI), Intracranial pressure (ICP), Glasgow Coma Scale (GCS)

\section{INTRODUCTION}

$\mathrm{T}$ The incidence of head injury has increased among pediatric patients. According to a statistics report in North America, more than 2.5 million cases of pediatric traumatic brain injury (TBI) are recorded annually, leading to
50,000 hospitalizations and causing more than $\$ 1$ billion of hospital charges. TBI is a leading cause of death in children. The most common causes of death are motor vehicle collisions in adolescents/young adults and falls in children younger than 4 years $(32,37)$.

\begin{tabular}{|c|c|c|c|c|}
\hline Burcu GOKER & (D) : :0000-0002-6084-8690 & M. Emre ALTUNRENDE & (1) : :0000-0003-3345-5821 & (1) : 0000-0002-5699-4089 \\
\hline D. Gucluhan GUCLU & (1) : 0000-0002-9959-961X & A. Tolgay AKINCI & (D) : 0000-0002-9937-076X & Altay SENCER (1) : 0000-0001-9925-5422 \\
\hline Ilyas DOLAS & (1) : :0000-0002-3425-3220 & Fahir SENCAN & (D) : 0000-0001-5519-5560 & \\
\hline Utku OZGEN & (D) : $0000-0001-8381-0700$ & Aydin AYDOSELI & (D) : 0000-0002-4695-8295 & \\
\hline
\end{tabular}


Pediatric patients may have better treatment outcomes than adult patients as they can recover from an extremely high intracranial pressure (ICP). Nevertheless, after a severe TBI, about $65 \%$ of pediatric patients present with high ICPs (60). In addition, more than half of TBI-related deaths are attributed to high ICP. Management strategies are limited, which include evacuating cerebrospinal fluid (CSF), decreasing blood or brain volume, inhibiting cerebral metabolic demands, and finally performing decompressive craniectomy (DC) to increase cranial volume. However, studies about the effects of DC on morbidity and mortality rates particularly in children must be conducted.

This retrospective clinical study aimed to evaluate the clinical outcomes of children who recently underwent DC due to high ICP correlated to head trauma or other causes, such as ischemic insult and hemorrhage.

\section{MATERIAL and METHODS}

Pediatric patients aged $\leq 17$ years who recently underwent DC due to high ICP between 2013 and 2018 were evaluated retrospectively. Neurological status upon admission [as assessed using the Glasgow Coma Scale (GCS) score, pupil reaction, and presence of neurologic deficits], initial cranial computed tomography (CT) findings, history of any surgical procedure (hematoma evacuation and external ventricular drainage placement), and course of each patient were recorded. In addition, the time interval between admission and indication of DC (deterioration of patient status and new CT scan findings) were determined. The type of surgery for decompression, patients' status, and outcomes after surgery were also assessed.

\section{RESULTS}

Twelve patients have undergone DC between 2013 and 2018. Among them, three were girls and nine were boys aged between 2 and 17 (mean age: 10) years. Seven patients were involved in a motor vehicle accident (MVA), three were injured from falling from a height, one had vascular injury after sustaining gunshot, and one was hit by a stone. MVA was more common in male than female patients (66\%) (Figure 1).

Eleven patients required intubation after trauma. Among them, three were intubated at the accident site, and the remaining eight were intubated in the emergency room. One patient was intubated while in the course of deterioration. Moreover, only one patient had multiple traumas, including thoracic and abdominal injuries, and none of the patients had spinal or maxillofacial pathologies. Initial neurological examination revealed that the average GCS score was 6 (3-12). The GCS score of two patients was low preoperatively.

The pupils of six (50\%) patients were isocoric during admission, and those of three (25\%) patients were anisocoric. Three (25\%) patients had fixed and dilated bilateral pupils. The GCS scores were lowest in the group with dilated pupils, which is an expected finding. The mean GCS score of the patients with isocoric pupils was 7 . Only one patient had focal neurologic deficit. Two patients with anisocoria and one patient with fixed bilateral pupils died.

Emergent CT scan was performed on all patients. Three patients had linear skull fractures, three depressed skull fractures, and three skull base fractures. All patients presented with signs of diffuse cerebral edema and subdural hematoma of various sizes. Three epidural hematomas, two intracerebral hematomas, four subarachnoid hemorrhages, and five multiple contusions were observed.

The mean time between admission and surgery was 8.75 (range: 2-60) hours. Eleven patients had a unilateral large hemispheric craniectomy, and one patient underwent bilateral frontal craniectomy. A craniectomy flap was commonly placed in the subcutaneous plane of the abdominal wall in 11 patients (Figure 2), and one flap was preserved at $-80^{\circ} \mathrm{C}$. In one patient, a craniectomy flap could not be used due to degradation. The patient then underwent cranioplasty 1 year after DC, and a

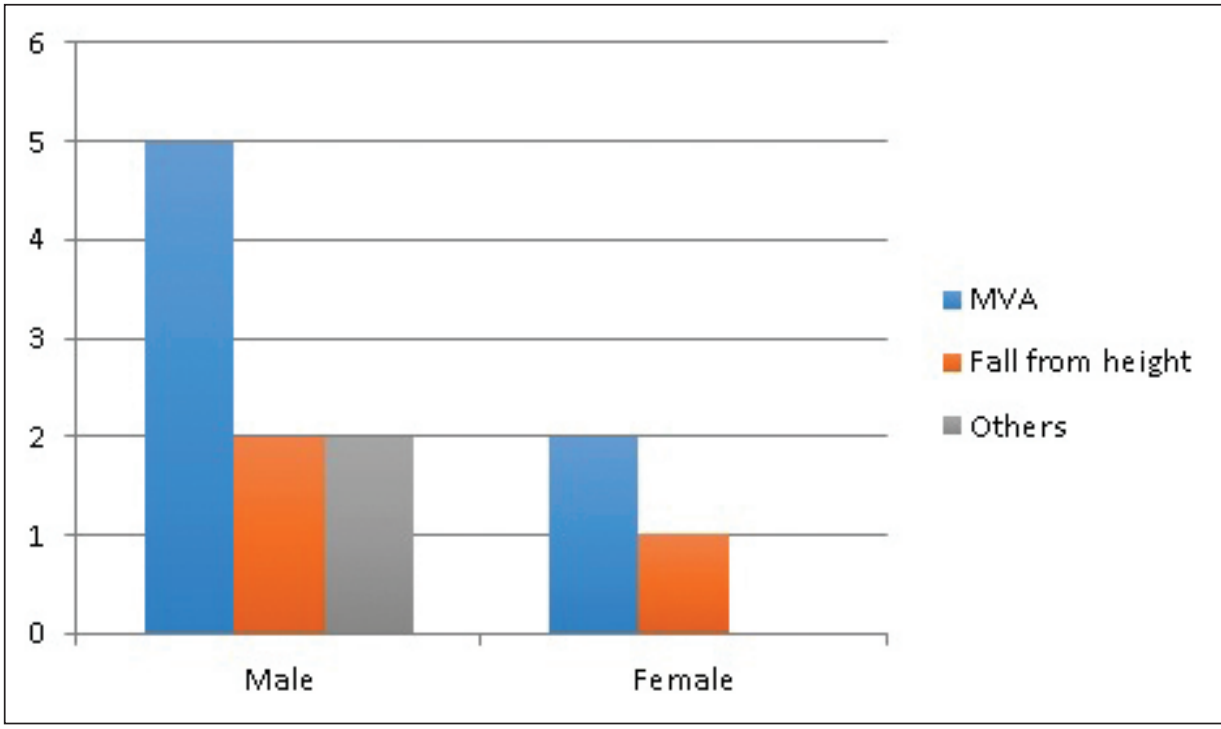

Figure 1: Differences in the etiology of trauma in terms of sex (MVA: motor vehicle accident). 
methyl methacrylate implant was used. Cranioplasty was commonly performed between 3 months to 1 year after DC.

The postoperative GCS score increased in eight patients. Two patients remained neurologically stable. However, the neurologic status of two patients worsened. Although DC was performed, three patients died. The mean outcome score was 3.25 (range: 1-5), with a mean follow-up of 6 (range: 4-12) months. Three patients had severe disability.

A 12-year old male patient sustained gunshot wound in the neck. He was transferred to our hospital for intensive care. During follow-up, the status of the patient deteriorated. Cranial CT scan showed infarct in the territory of the right middle cerebral artery. He underwent surgery 6 hours after his

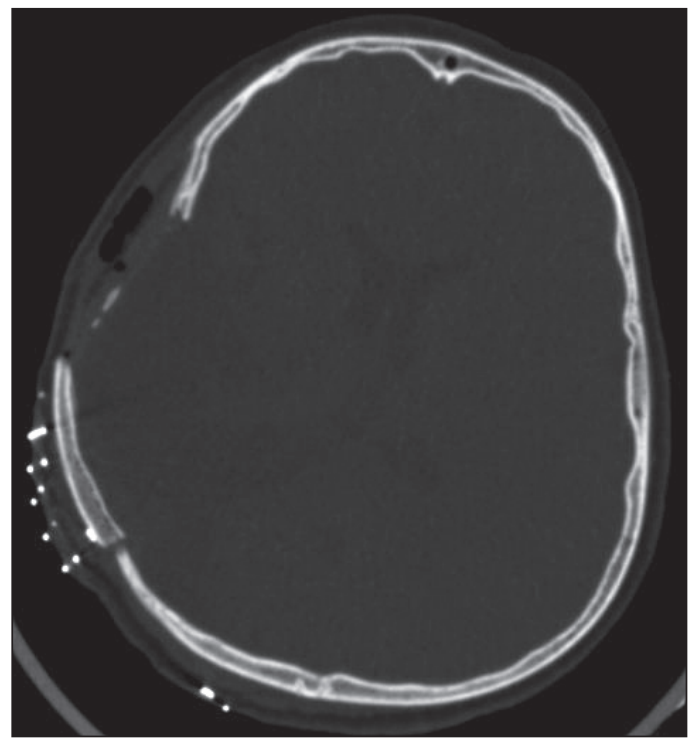

Figure 2: Postoperative CT scan of a patient who underwent cranioplasty. The patient's own bone graft, which was preserved in the subcutaneous tissue, was used. first admission. Eight months after discharge, he underwent re-surgery for cranioplasty (Figures 3A, B).

\section{DISCUSSION}

The main goal in the management of head injury is to prevent secondary injury mainly caused by intracranial hypertension and reduced cerebral perfusion pressure. In recent decades, as a lifesaving intervention, DC has a progressively growing role in the management of intracranial hypertension due to traumatic brain injury or acute ischemic stroke in adult patients (53). In particular, in the latest guidelines published by the Brain Trauma Foundation in 2016, the recommendations for the management of DC were updated. That is, a large frontotemporoparietal DC $(\geq 15 \mathrm{~cm}$ in diameter) was recommended over a smaller one to reduce mortality and improve outcome in patients with severe TBI at a IIA recommendation level (7). Moreover, in March 2019, the updated guidelines for the management of severe TBI among pediatric patients were published, and DC was recommended for the treatment of neurological deterioration, herniation, or intracranial hypertension refractory to medical management at level III recommendation $(7,27)$. The difference between the recommendation levels for adult and pediatric patients (level Ila and level III, respectively) indicates that a low quality and quantity of evidence on the use of DC in children with severe TBI.

Recently, DC was considered unnecessary and redundant in clinical practice. Thus, conservative measures, such as use of hyperosmolar agents and barbiturates, CSF drainage, and sedation, were considered (24). However, even shortterm increases in ICP (over $40 \mathrm{~mm} \mathrm{Hg}$ ) are associated with important and irreversible brain damage (7). Moreover, other second-line treatments may have more disadvantages than advantages. Barbiturate coma therapy, an accepted neuroprotective measure, increases the risk of complications, such as hypothermia and hypotension, and there is still no
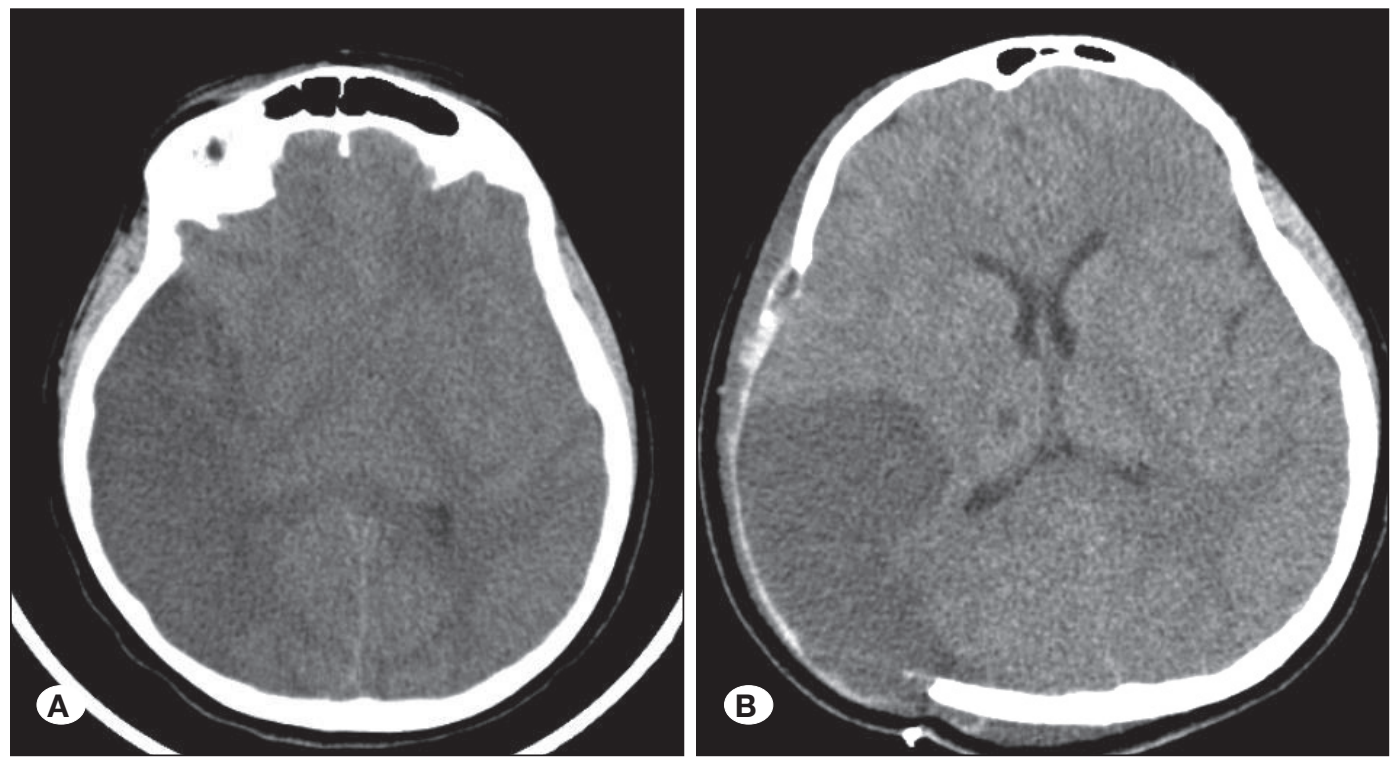

Figure 3: A) Shows the preoperative computed tomography (CT) scan image of a patient. The hypodense area represents infarct in the territory of the right middle cerebral artery. B) Shows the early postoperative cranial CT scan of the same patient Reappearance of the ventricles that previously disappeared is obvious. 
consensus about its goals and methods $(6,10,12,16,18,19,23$ $, 25,34,35,40,42,47,48,54,57,60)$.

The results of most studies about the recommended craniectomy technique are consistent. To date, small temporal craniectomies are not used. A large frontotemporoparietal flap is commonly removed. If diffuse brain swelling or lesions in both sides of the brain are observed, large bifrontal craniectomies are performed. The dura is usually opened and exposed, and the brain is covered with the remaining dura and autologous fascia $(9,20,21)$. In all patients $(n=12)$, the dura was opened in accordance with the literature, and duraplasty with autologous fascia was performed.

One of the most frequently encountered problems after DC is hydrocephalus. Approximately $14 \%-29 \%$ of adults present with such condition $(1,49,59)$. However, the actual incidence in children is not known. In our study, none of the patients developed hydrocephalus after DC.

Bone flap is commonly replaced weeks to months after surgery. The use of the original flap or synthetic cranioplasty is the main option $(56,59)$. Bone flap can be stored in the abdominal wall of the patient or in a certified tissue bank. Today, three-dimensional printers are used to mold synthetic grafts to achieve the most accurate shapes. In our series, the craniectomy flap was placed in the subcutaneous tissue of the abdominal wall, and one flap was stored in the freezer.

Ideally, DC should be performed within the first 48 hours after TBI or the onset of intracranial hypertension $(21,41)$. In addition, several reports have indicated that DC should be performed at an early stage in pediatric patients to achieve better outcomes $(21,42,55)$. In our patients, the mean time between admission and surgery was 8.75 (range: 2-60) hours.

Although the condition of children improves after severe TBI, currently, patients cannot be classified according to age groups, such as younger than 2, 2-6, 6-12, and 12-18 years (21). Since there is a small number of patients included in the study, such stratification was not performed.

The prognosis after trans-tentorial herniation is usually poor. A good prognosis is achieved in $27 \%$ of patients with unilateral dilated pupils and $3.5 \%$ with bilateral dilated pupils $(4,21,44)$. In our series, the pupils of six (50\%) patients were isocoric during admission, and those of three $(25 \%)$ patients were anisocoric. Moreover, three (25\%) patients had fixed and dilated bilateral pupils. Only one (33.3\%) of three patients who had fixed and dilated pupils survived and underwent cranioplasty, and the two other patients who had anisocoric pupils died. The GCS scores were lowest in the group with fixed and dilated pupils.

ICP monitoring is included in the guidelines on the management of severe TBI. Although numerous studies, including the BEST-TRIP trial, have shown that ICP monitoring did not have any effect on prognosis, some reports have revealed better mortality and morbidity rates $(2,8,11,14,29,43)$. In ICP monitoring, the threshold for DC in adults and children is controversial. Some centers use a threshold of $15 \mathrm{mmHg}$ for children $(13,22,36)$. In our study, due to financial constraints, ICP monitoring was not performed.
Malignant stroke may be observed in some patients with ischemic cerebral infarction (5), which is characterized by progressive edema and increased intracranial pressure leading to trans-tentorial herniation and deterioration and loss of patient. Recently, DC has gained wide acceptance and is considered an effective surgical intervention for the management of these patients. However, as the occurrence of ischemic stroke is extremely rare in children, with an incidence of 1.2-3.6 cases per 100,000 per year, and less than $2 \%$ of patients present with malignant ischemic strokes, knowledge about the management of children with these conditions who underwent DC is extremely limited $(3,15,17,26,28,30,31,33,38$, $39,45,46,50-52,58)$. In our clinical series, one child (aged 11 years) with gunshot wound in the neck and carotid artery dissection developed cerebral infarction with symptoms of progressive herniation. However, the patient recovered well after DC.

\section{CONCLUSION}

As previously mentioned, information about the benefits or complications of DC in children remains limited. With the increasing use and success of DC in adults, this procedure can also be effective in children. However, considering brain differences in children, large and well-structured clinical trials must be conducted to prevent complications and to identify the best techniques, timing, and actual benefits of DC for children.

\section{REFERENCES}

1. Aarabi B, Hesdorffer DC, Ahn ES, Aresco C, Scalea TM, Eisenberg HM: Outcome following decompressive craniectomy for malignant swelling due to severe head injury. J Neurosurg 104:469-479, 2006

2. Adelson PD, Bratton SL, Carney NA, Chesnut RM, du Coudray HE, Goldstein B, Kochanek PM, Miller HC, Partington MD, Selden NR, Warden CR, Wright DW: Guidelines for the acute medical management of severe traumatic brain injury in infants, children, and adolescents. Chapter 1: Introduction. Pediatr Crit Care Med 4:S2-S4, 2003

3. Aghakhani N, Durand P, Chevret L, Parker F, Devictor D, Tardieu M, Tadié M: Decompressive craniectomy in children with nontraumatic refractory high intracranial pressure. J Neurosurg Pediatr 3:66-69, 2009

4. Andrews BT, Pitts LH: Functional recovery after traumatic transtentorial herniation. Neurosurgery 29:227-231, 1991

5. Beez T, Munoz-Bendix C, Steiger HJ, Beseoglu K: Decompressive craniectomy for acute ischemic stroke. Crit Care 23:209, 2019

6. Bruce DA, Alavi A, Bilaniuk L, Dolinskas C, Obrist W, Uzzell B: Diffuse cerebral swelling following head injuries in children: The syndrome of "malignant brain edema". J Neurosurg 54:170-178, 1981

7. Carney N, Totten AM, O'Reilly C, Ullman JS, Hawryluk GW, Bell MJ, Bratton SL, Chesnut R, Harris OA, Kissoon N, Rubiano AM: Guidelines for the management of severe traumatic brain injury, $4^{\text {th }}$ ed. Neurosurgery 80:6-15, 2017 
8. Chesnut RM, Temkin N, Carney N, Dikmen S, Rondina C, Videtta W, Petroni G, Lujan S, Pridgeon J, Barber J, Machamer $\mathrm{J}$ : A trial of intracranial-pressure monitoring in traumatic brain injury. N Engl J Med 367:2471-2481, 2012

9. Cook DJ, Guyatt GH, Laupacis A, Sackett DL: Rules of evidence and clinical recommendations on the use of antithrombotic agents. Chest 102:305S-311S, 1992

10. Cordobes F, Lobato RD, Rivas JJ, Portillo JM, Sarabia M, Munoz MJ: Post-traumatic diffuse brain swelling: Isolated or associated with cerebral axonal injury. Clinical course and intracranial pressure in 18 children. Childs Nerv Syst 3:235238, 1987

11. Cremer OL, van Dijk GW, van Wensen E, Brekelmans GJ, Moons KG, Leenen LP, Kalkman CJ: Effect of intracranial pressure monitoring and targeted intensive care on functional outcome after severe head injury. Crit Care Med 33:22072213, 2005

12. Cruz J: Adverse effects of pentobarbital on cerebral venous oxygenation of comatose patients with acute traumatic brain swelling: Relationship to outcome. J Neurosurg 85:758-761, 1996

13. Csókay A, Emelifeonwu JA, Fügedi L, Valálik I, Láng J: The importance of very early decompressive craniectomy as a prevention to avoid the sudden increase of intracranial pressure in children with severe traumatic brain swelling (retrospective case series). Child's Nerv Syst 28:441-444, 2012

14. Farahvar A, Gerber LM, Chiu Y-L, Carney N, Härtl R, Ghajar $\mathrm{J}$ : Increased mortality in patients with severe traumatic brain injury treated without intracranial pressure monitoring. J Neurosurg 117: 729-734, 2012

15. Farooq MU, Abbed KM, Fletcher JJ: Decompressive hemicraniectomy in a 19-month-old female after malignant cerebral infarction. Pediatr Neurosurg 45:146-150, 2009

16. Figaji AA, Fieggen AG, Argent AC, Le Roux PD, Peter JC: Intracranial pressure and cerebral oxygenation changes after decompressive craniectomy in children with severe traumatic brain injury. Acta Neurochir Suppl 102:77-80, 2008

17. Fischer EG, Strand RD, Gilles FH: Cerebellar necrosis simulating tumor in infancy. J Pediatr 81:98-100, 1972

18. Gower DJ, Lee KS, Mc Whorter JM: Role of subtemporal decompression in severe closed head injury. Neurosurgery 23:417-422, 1988

19. Guerra WK, Gaab MR, Dietz H, Mueller JU, Piek J, Fritsch MJ: Surgical decompression for traumatic brain swelling: Indications and results. J Neurosurg 90:187-196, 1999

20. Guresir E, Raabe A, Setzer M, Vatter H, Gerlach R, Seifert V, Beck J: Decompressive hemicraniectomy in subarachnoid haemorrhage: The influence of infarction, haemorrhage and brain swelling. J Neurol Neurosurg Psychiatry 80:799-801, 2009

21. Guresir E, Schuss P, Seifert V, Vatter H: Decompressive craniectomy in children. Neurosurgery 70:881-889, 2012

22. Jagannathan J, Okonkwo DO, Dumont AS, Ahmed H, Bahari A, Prevedello DM, Jane JA: Outcome following decompressive craniectomy in children with severe traumatic brain injury: A 10 -year single-center experience with long-term follow up. J Neurosurg 106:268-275, 2007
23. Jennett $B$, Bond M: Assessment of outcome after severe brain damage. Lancet 1:480-484, 1975

24. Josan VA, Sgouros S: Early decompressive craniectomy may be effective in the treatment of refractory intracranial hypertension after traumatic brain injury. Child's Nerv Syst 22:1268-1274,2006

25. Kirkham FJ, Neville BG: Successful management of severe intracranial hypertension by surgical decompression. Dev Med Child Neurol 28:506-509, 1986

26. Kirton A, DeVeber G: Ischemic stroke complicating pediatric cardiovascular disease. Nat Clin Pract Cardiovasc Med 4:163166, 2007

27. Kochanek PM, Tasker RC, Carney N, Totten AM, Adelson PD, Selden NR, Davis-O'Reilly C, Hart EL, Bell MJ, Bratton SL, Grant GA, Kissoon N, Reuter-Rice KE, Vavilala MS, Wainwright MS: Guidelines for the management of pediatric severe traumatic brain injury, $3^{\text {rd }}$ ed. Pediatr Crit Care Med 20:280-289, 2019

28. Lammy S, Fivey P, Sangra M: Decompressive craniectomy for malignant middle cerebral artery infarction in a 16-year old boy: A case report. J Med Case Rep 10:368, 2016

29. Lane PL, Skoretz TG, Doig G, Girotti MJ: Intracranial pressure monitoring and outcomes after traumatic brain injury. Can $\mathrm{J}$ Surg 43:442-448, 2000

30. Lee MC, Frank JI, Kahana M, Tonsgard JH, Frim DM: Decompressive hemicraniectomy in a 6-year-old male after unilateral hemispheric stroke. Case report and review. Pediatr Neurosurg 38:181-185, 2003

31. Lee SK, Kim SD, Kim SH, Lim DJ, Park JY: Decompressive hemicraniectomy and duroplasty in toddlers and preschool children with refractory intracranial hypertension after unilateral hemispheric stroke. J Korean Neurosurg Soc 51:8690, 2012

32. Leetch AN, Wilson B: Pediatric major head injury. Emerg Med Clin North Am 36:459-472, 2018

33. Leonhardt G, Wilhelm H, Doerfler A, Ehrenfeld CE, Schoch $B$, Rauhut F, Hufnagel A, Diener HC: Clinical outcome and neuropsychological deficits after right decompressive hemicraniectomy in MCA infarction. J Neurol 249:1433-1440, 2002

34. Maas AI, Dearden M, Teasdale GM, Braakman R, Cohadon F, lannotti F, Karimi A, Lapierre F, Murray G, Ohman J, Persson $\mathrm{L}$ : EBIC-guidelines for management of severe head injury in adults. European Brain Injury Consortium. Acta Neurochir (Wien) 139:286-294, 1997

35. Marshall LF, Marshall SB, Klauber MR, Van MB, Eisenberg $H$, Jane JA, Luerssen TG, Marmarou A, Foulkes MA: The diagnosis of head injury requires a classification based on computed axial tomography. J Neurotrauma 9:S287-S292, 1992

36. Mazzola CA, Adelson PD: Critical care management of head trauma in children. Crit Care Med 30:S393-S401, 2002

37. Mhanna MJ, Mallah WE, Verrees M, Shah R, Super DM: Outcome of children with severe traumatic brain injury who are treated with decompressive craniectomy. J Neurosurg Pediatr 16:508-514, 2015 
Goker B. et al: Decompressive Craniectomy in Children

38. Miyata I, Imaoka T, Masaoka T, Nishiura T, Ishimitsu H: Pediatric cerebellar infarction caused by atlantoaxial subluxation-case report. Neurol Med Chir (Tokyo) 34:241-245, 1994

39. Montgomery AK, Maixner WJ, Wallace D, Wray A, Mackay MT: Decompressive craniectomy in childhood posterior circulation stroke: A case series and review of the literature. Pediatr Neurol 47:193-197, 2012

40. Münch E, Horn P, Schürer L, Piepgras A, Paul T, Schmiedek $P$ : Management of severe traumatic brain injury by decompressive craniectomy. Neurosurgery 47:315-322; discussion 322-323, 2000

41. Pérez Suárez E, Serrano González A, Pérez Díaz C, García Salido A, Martínez de Azagra Garde A, Casado Flores J: Decompressive craniectomy in 14 children with severe head injury: Clinical results with long-term follow-up and review of the literature. J Trauma 71:133-140, 2011

42. Polin RS, Shaffrey ME, Bogaev CA, Tisdale N, Germanson T, Bocchicchio B, Jane JA: Decompressive bifrontal craniectomy in the treatment of severe refractory posttraumatic cerebral edema. Neurosurgery 41:84-92; discussion 92-94, 1997

43. Prasad GL, Gupta DK, Mahapatra AK, Sharma BS: Surgical results of decompressive craniectomy in very young children: A level one trauma centre experience from India. Brain Inj 29:1717-1724, 2015

44. Prasad MR, Ewing-Cobbs L, Swank PR, Kramer L: Predictors of outcome following traumatic brain injury in young children. Pediatr Neurosurg 36:64-74, 2002

45. Rahme R, Jimenez L, Bashir U, Adeoye OM, Abruzzo TA, Ringer AJ, Kissela BM, Khoury J, Moomaw CJ, Sucharew H, Ferioli S: Malignant MCA territory infarction in the pediatric population: Subgroup analysis of the Greater Cincinnati/ Northern Kentucky Stroke Study. Childs Nerv Syst 29:99-103, 2013

46. Ramaswamy V, Mehta V, Bauman M, Richer L, Massicotte P, Yager JY: Decompressive hemicraniectomy in children with severe ischemic stroke and life-threatening cerebral edema. J Child Neurol 23:889-894, 2008

47. Rekate HL: Head injuries: Management of primary injuries and prevention of secondary damage. Child's Nerv Syst 17:632634, 2001

48. Schalén W, Messeter K, Nordström $\mathrm{CH}$ : Complications and side effects during thiopentone therapy in patients with severe head injuries. Acta Anaesthesiol Scand 36:369-377, 1992

49. Schuss P, Borger V, Guresir Á, Vatter H, Guresir E: Cranioplasty and ventriculoperitoneal shunt placement after decompressive craniectomy: Staged surgery is associated with fewer postoperative complications. World Neurosurg 84:1051-1054, 2015
50. Shah S, Murthy SB, Whitehead WE, Jea A, Nassif LM: Decompressive hemicraniectomy in pediatric patients with malignant middle cerebral artery infarction: Case series and review of the literature. World Neurosurg 80:126-133, 2013

51. Smith SE, Kirkham FJ, Deveber G, Millman G, Dirks PB, Wirrell E, Telfeian AE, Sykes K, Barlow K, Ichord R: Outcome following decompressive craniectomy for malignant middle cerebral artery infarction in children. Dev Med Child Neurol 53:29-33, 2011

52. Tan MA, Salonga AM, Jamora RDG: Decompressive hemicraniectomy in a 2-year-old girl with a left middle cerebral artery infarct. Childs Nerv Syst 22:523-525, 2006

53. Tang Z, Huang Q, Zhang J, Yang R, Wei W, Liu H: Fourteenday mortality in pediatric patients with traumatic brain injury after early decompressive craniectomy: A single-center retrospective study. World Neurosurg 119:e389-e394, 2018

54. Taylor A, Butt W, Rosenfeld J, Shann F, Ditchfield M, Lewis E, Klug G, Wallace D, Henning R, Tibballs J: A randomized trial of very early decompressive craniectomy in children with traumatic brain injury and sustained intracranial hypertension. Childs Nerv Syst 17:154-162, 2001

55. Thomale UW, Graetz D, Vajkoczy P, Sarrafzadeh AS: Severe traumatic brain injury in children-a single center experience regarding therapy and long-term outcome. Childs Nerv Syst 26:1563-1573, 2010

56. Tsang AC, Hui VK, Lui WM, Leung GK: Complications of post-craniectomy cranioplasty: Risk factor analysis and implications for treatment planning. J Clin Neurosci 22:834837, 2015

57. Venes JL, Collins WF: Bifrontal decompressive craniectomy in the management of head trauma. J Neurosurg 42:429-433, 1975

58. Yamaguchi $H$, Yamamoto $K$, Akutsu $N$, Kusumoto $M$, Kajihara S, Yamaguchi Y, Takeda H, Kawamura A, Uetani Y: Decompressive craniectomy $116 \mathrm{~h}$ after malignant middle cerebral artery infarction. Pediatr Int 58:622-624, 2016

59. Young $\mathrm{AMH}$, Kolias AG, Hutchinson PJ: Decompressive craniectomy for traumatic intracranial hypertension: Application in children. Child's Nerv Syst 33:1745-1750, 2017

60. Whitfield PC, Patel H, Hutchinson PJ, Czosnyka M, Parry D, Menon D, Pickard JD, Kirkpatrick PJ: Bifrontal decompressive craniectomy in the management of post traumatic intracranial hypertension. Br J Neurosurg 15:500-507, 2001 